\title{
MODEL PEMURIDAN AKSELERASI YESUS KRISTUS DALAM MULTIPLIKASI JEMAAT DI GEREJA SIDANG JEMAAT ALLAH SURAKARTA
}

\author{
Irawan Budi Lukmono \\ Dosen Tetap Sekolah Tinggi Teologi Gamaliel Surakarta \\ Email: ibel_choy@yahoo.co.id
}

\begin{abstract}
The objective of this research is to explain the accelerated discipleship model of Jesus Christ according to the Synoptic gospels and modern discipleship experts to multiplicate the church members of GSJA (Church of General Assembly) Surakarta.

The research method here is a qualitative research with literature study consists of: books, papers, magazines, website, reports, and other writings data related to the research questions.

From the result of the research, then the researcher propose a Model of Accelerated Discipleship to Multiplicate Church Member in GSJA Surakarta consists some aspects as follow: first, biblical and contextual discipleship history; second, discipleship principles (selection or screening), training center (training, development, anointing, exampling), multiplication (sending, controlling, multiplication); third, discipleship components, such as: teacher (Jesus Christ-The Great Teacher, Hoy Spirit The Councelor, teacher/trainer), relationship (friendship, interdependent), subject matter and curriculum (The Bible, KTBK series), method (inductive contextual), discipleship acceleration, and output of discipleship; fourth, discipleship acceleration; and fifth, result of discipleship.
\end{abstract}

Keywords: Discipleship, Acceleration, Jesus Christ, Multiplication of Church Member

Penelitian ini bertujuan untuk: menjelaskan model pemuridan akselerasi Yesus Kristus menurut Injil Sinoptik dan para pakar pemuridan modern dalam multiplikasi jemaat di GSJA Surakarta.

Metode penelitian ini adalah penelitian kualitatif dengan studi literatur yang terdiri dari: bukubuku, artikel, majalah, situs di internet, laporan dan data tertulis lain yang berhubungan dengan masalah penelitian.

Dari hasil penelitian ini, maka penulis mengusulkan suatu Model Pemuridan Akselerasi dalam Multiplikasi Jemaat di GSJA Surakarta yang dijabarkan sebagai berikut: pertama, sejarah pemuridan yang alkitabiah dan kontekstual. Kedua, prinsip-prinsip pemuridan ( seleksi atau screening), pusat atau pelatihan training center (pelatihan, pengembangan, pembinaan, pengurapan, peneladanan), multiplikasi (pengutusan, pengawasan, pelipatgandaan). Ketiga, komponen pemuridan antara lain: guru (Guru Agung Yesus Kristus, Roh Kudus Pembimbing, PKKA, pemurid, pembimbing, pengajar, pelatih, pelayan, tim pelayan atau tubuh Kristus, memiliki karunia berbeda-beda), murid, relasi ( persahabatan, interdependensi), materi \& kurikulum (alkitab, seri bahan yang kontekstual), metode (induktif-kontekstual), akselerasi pemuridan, dan hasil pemuridan. Keempat, akselerasi pemuridan. Kelima, hasil pemuridan.

Kata Kunci: Pemuridan, Akselerasi, Yesus Kristus, Multiplikasi Jemaat di Gereja 
Ia memulai pelayanan dengan memberitakan Injil dan memuridkan para murid dengan dampak yang nyata dan proses pelipatgandaan (multiplikasi)

\section{Pendahuluan}

Pemuridan merupakan tugas mulia bagi gereja (Mat. 28:19-20) yang harus diemban, dijaga dan dilaksanakan terus menerus, sehingga gereja dapat menggarami dan menerangi dunia, serta membawa jiwa kepada Kristus, beriman, bertumbuh, dewasa di dalam Yesus Kristus dan menjadi murid Kristus yang sejati. Gereja harus menjadi murid Kristus yang bersaksi kepada dunia sekitar. Menjadi murid Kristus adalah pilihan mutlak bagi orang percaya. Semua orang percaya adalah murid Kristus (Kis. 6:1, 2, 7; 11:26; 14:20, 22-15:10). ${ }^{1}$

Gereja harus memiliki visi yang besar yaitu semua bangsa menjadi murid Kristus (Mat. 28:19). ${ }^{2}$ Gereja adalah agen misi Allah untuk melaksanakan proyek pemuridan. Gereja dipanggil untuk menceritakan cinta kasih Allah, keselamatan, dan berkat-berkat yang Allah melalui sebuah pemuridan. Gereja memiliki tugas dan tanggungjawab membina, melatih dan melibatkan jemaat melalui pemuridan, sehingga menghasilkan banyak jiwa yang bertumbuh dewasa dalam Tuhan Yesus Kristus.

Kisah Yesus Kristus di dalam Injil Sinoptik merupakan fakta dari kehidupan Sang Guru Agung yang melaksanakan pemuridan. Yesus memberi teladan pemuridan kepada murid-murid-Nya dengan tujuan utama untuk memilih orang-orang yang dapat memberi kesaksian tentang hidup-Nya, dan melanjutkan pekerjaan-Nya. ${ }^{3}$

${ }^{1}$ Eddy Leo, Murid Sejati: Suatu Pilihan Mutlak, (Jakarta: Metanoia, 2003), 2.

${ }^{2}$ Agustinus Titi, Kuasa Kelompok Kecil Pemuridan (Bekasi: Saint Andrew's Ministry, 2007), 2.

${ }^{3}$ Robert E. Coleman, Rencana Agung

Penginjilan, (Bandung: Kalam Hidup, 2004), 23. yang luar biasa, bahkan Injil diberitakan sampai ke ujung bumi. Yesus hanya membutuhkan waktu sekitar tiga setengah tahun untuk memuridkan. Yesus mampu melatih para murid menjadi murid yang sejati dan pemurid dengan kapasitas rohani penuh sebagai murid Kristus. ${ }^{4}$ Model pemuridan Yesus yang begitu cepat, namun berkualitas ini dapat dikatakan sebagai model pemuridan dengan menggunakan sistem akselerasi (sistem percepatan). Sistem akselerasi adalah model pembelajaran oleh guru yang berkualitas kepada murid yang diidentifikasikan memiliki kemampuan yang lebih untuk dapat menyelesaikan program pendidikan (pemuridan) dengan cepat. ${ }^{5}$

Gereja Sidang Jemaat Allah (GSJA) merupakan salah satu denominasi gereja yang sudah lama hadir dan ada di Indonesia, yaitu sejak 4 April 1941. ${ }^{6}$ Tahun 1956 GSJA memiliki 35 gereja, 11 pelayan Injil dengan jemaat sebanyak 2085 jiwa. $^{7}$ Tahun 1956 sampai dengan tahun 2007 terjadi perubahan jumlah jemaat yaitu 174.036 jiwa. Akan tetapi dari tahun 2007 sampai dengan tahun 2008 mengalami penurunan jumlah jemaat menjadi 173.365 jiwa. $^{8}$ Penurunan jiwa sebesar 631 jiwa dalam setahun

Pada tahun 2009 jumlah jemaat GSJA adalah 178.908 jiwa dan tahun 2010 sebanyak

${ }^{4}$ A.B. Bruce, The Training of The Twelve, (Grand Rapid: Kregel Publication, 1984), 20.

${ }^{5}$ www.tawil-umm.blogspot.com

${ }^{6}$ www.gsja.org

${ }^{7}$ Gani Wiyono, Gereja Sidang-sidang Jemaat Allah dalam Lintasan Sejarah, (Malang: Gandum Mas, 2007), 146.

${ }^{8}$ GSSJA, Laporan Badan Pengurus Pusat Periode 2007-2011, (Jakarta: GSSJA, 2011), 5. 
196.740 jiwa. Dalam kurun waktu satu tahun (20102011) terjadi penurunan jiwa sebanyak 2.352 jiwa. Pada tahun 2011 ini jumlah jemaat adalah 194.388 jiwa. ${ }^{9}$ Padahal jika dilihat dari statistik jumlah gereja GSJA di Indonesia mengalami peningkatan antara tahun 2007-2011, dimana jumlah gereja sebanyak 2.013 (tahun 2007) dan 2.161 (tahun 2011). ${ }^{10}$ Data ini merupakan hasil penelitian dari Departemen Penelitian dan Pengembangan GSJA.

Penyebab umum terjadinya penurunan jumlah jemaat adalah masalah sumber daya manusia yang kurang dididik dan dilatih dalam pendidikan misi dan pemuridan, khususnya jemaat dalam gereja lokal. Selain itu, proses perencanaan, pelaksanaan, pengawasan dan perbaikan berkaitan dengan visi GSJA tidak berjalan dengan semestinya. ${ }^{11}$

Budi Setiawan, Sekretaris Umum GSSJA Indonesia menulis tentang keprihatinannya terhadap pemuridan di GSJA, demikian:

"Kita kurang memiliki sistem pemuridan sebagaimana seharus-nya ada dan yang diperlukan untuk keberlanjutan suatu pelayanan. Bukan bahan pemuridan yang saya maksud, tetapi suatu budaya memuridkan orang lain di mana seorang rohaniwan memberikan waktu kepada satu atau dua orang lainnya untuk memberi pengetahu-an, menunjukkan contoh, melatih secara sengaja, mengawasi perkem-bangan dan melepas dalam kematangan. Bahkan dalam bebe-rapa hal, memberi kehidupan kepada mereka."12

Data di atas menunjukkan bahwa GSJA Indonesia sedang mengalami persoalan pemuridan yang sangat serius, dimana kondisi jemaat menurun, karena kurang kuatnya pemuridan.

\footnotetext{
${ }^{9}$ Ibid, 5.

${ }^{10}$ Ibid.

${ }^{11}$ Ibid, 10.

${ }^{12}$ www.gsja.org
}

GSJA telah melakukan pemuridan, akan tetapi faktanya adalah terjadi kelambanan dalam multiplikasi dan menurunnya jumlah jemaat. Persoalan pemuridan ini menunjukkan indikasi kurangnya fokus dan perhatian terhadap pemuridan di gereja. Apabila hal ini tidak segera dilakukan tindakan serius dan dicari jalan keluar, maka GSJA akan menjadi denominasi gereja yang mengalami penurunan kualitas dan kuantitas jemaat.

Permasalahan di atas mendorong penulis untuk meneliti model pemuridan akselerasi di dalam multiplikasi jemaat. Penelitian ini dilakukan dengan harapan GSJA memperoleh penjelasan mengenai model pemuridan akselerasi Yesus Kristus yang alkitabiah dan dapat diaplikasikan pada masa kini.

Permasalahan penelitian ini lebih terfokus kepada penjelasan tiga sub masalah. Pertama, bagaimana model pe-muridan akselerasi Yesus Kristus menurut Injil Sinoptik dan pakar pemuridan modern?

Kedua, bagaimana model pemu-ridan dalam multiplikasi jemaat di GSJA Surakarta (tahun 20072011)?

Ketiga, bagaimana perbandingan (komparasi) antara model pemuridan akselerasi Yesus Kristus menurut Injil Sinoptik dan para pakar pemuridan modern, dengan pemuridan dalam multiplikasi jemaat di GSJA Surakarta?

\section{Metodologi Penelitian}

Penelitian pada prinsipnya merupa-kan suatu kegiatan atau proses meng-ungkapkan rahasia sesuatu yang tentunya belum diketahui, dengan mempergunakan metode dan cara bekerja yang sistematik serta terarah. ${ }^{13}$

Penelitian ini adalah penelitian kualitatif, yaitu suatu proses menjaring informasi, dari kondisi sewajarnya dalam kehidupan suatu obyek,

\footnotetext{
${ }^{13}$ Hadari Nawawi \& Martini Hadari, Instrumen Penelitian Bidang Sosial, (Yogyakarta: Gadjah Mada University Press, 1991), 208.
} 
dikorelasikan dengan pemecahan suatu masalah, baik dari sudut pandangan teoritis maupun praktis. ${ }^{14}$

Pendekatan yang dilakukan di dalam penelitian ini adalah perbandingan (studi komparatif), deskriptis-analitis. Dikatakan perbandingan dalam arti metode ini menyoroti teks dengan membandingkan dan mempertentangkan-nya dengan bagian-bagian lain yang berkaitan. ${ }^{15}$ Di dalam pendekatan des-kriptis, pada awalnya data dikumpulkan, dijelaskan dan disimpulkan. Sedangkan pendekatan analitis dilakukan sesudah data yang dikumpulkan akan mengalami proses organisasi dan urutan ke dalam pola, kategori dan satuan uraian dasar sehingga dapat ditemukan tema dan dapat dirumuskan dalam ide seperti yang disarankan oleh data. ${ }^{16}$

\section{Pengumpulan Data}

Penelitian ini adalah penelitian kualitatif, oleh karena itu data juga bersifat kualitatif, yaitu tidak meng-gambarkan jumlah atau bilangan yang memiliki perbandingan yang pasti. ${ }^{17}$ Penelitian ini merupakan studi literatur yang terdiri dari: bukubuku, artikel, majalah, situs di internet, laporan dan data tertulis lain yang berhubungan dengan masalah penelitian. ${ }^{18}$

Beberapa langkah yang akan dilakukan dalam pengumpulan data adalah: pertama, mengumpulkan data tentang pemuridan Yesus Kristus melalui penyelidikian Alkitab secara induktif terhadap Injil Sinoptik. Data-data tersebut didukung dengan buku-buku diantaranya adalah: Jesus of The Gospels karya Michael Eaton, Yesus karya Leith

\footnotetext{
${ }^{14}$ Ibid, 209.

${ }^{15}$ Andreas Bambang Subagyo, Pengantar
} Riset Kuantitatif \& Kualitatif, (Bandung: Kalam Hidup, 2004), 144.

${ }^{16}$ Lexy J. Moleong, Metodologi Penelitian Kualitatif, (Bandung: Remaja Rosdakarya, 2001), 280.

${ }^{17}$ Andreas Bambang Subagyo, 208.

${ }^{18}$ Lexy J. Moleong, 113.
Anderson, Pemberitaan tentang Yesus menurut Injil Sinoptik karya Samuel Benyamin Hakh, kemudian Kuasa Kelompok Kecil Pemuridan karya Agustinus Titi, Alkitab Penuntun Hidup Berke-limpahan karya Stanley Horton, Tafsir Alkitab Masa kini karya Donald Gutrie, Rencana Agung Penginjilan karya Robert E. Coleman, Tafsir Alkitab Perjanjian Baru karya Dianne Bergant dan Robert J. Karris dan sebagainya.

Kedua, mencari dan mengumpulkan datadata tentang teori pemuridan dari berbagai buku, antara lain: Penggandaan Murid-murid karya Waylon B. Moore, Pedoman Pemuridan karya Hartman \& Sutherland, Murid Sejati Suatu Pilihan Mutlak karya Eddy Leo, Pemuridan Seni yang Hilang karya Le Roy Eims, Pemuridan dengan Prinsip Timotius karya Roy Robertson, dan Jurnal Aletheia karya T. Haryono.

Ketiga, mencari data-data sejarah perkembangan gereja lokal (GSJA), pendidikan pemuridan jemaat GSJA, dari berbagai sumber tertulis yang dipublikasikan antara lain: Gereja Sidang-sidang Jemaat Allah Dalam Lintasan Sejarah karya Gani Wiyono, Doktrin Alkitab (GSJA) dan Gereja \& Tugas Misi dan Pemuridan karya Stanley Horton, Kerygma dan Pedoman Kelompok Keluarga Allah (Pemuridan) diterbitkan oleh Departemen Media GSSJA, dan Kumpulan Pembahasan dan Keputusan Rapat Majelis Pusat terbitan GSSJA Indonesia.

Keempat, mengumpulkan informasi pemuridan, akselerasi pemuridan dan kendalakendalanya melalui wawancara dari beberapa tokoh GSJA. Tokoh-tokoh tersebut antara lain: Pdt. Obed Batlayar (Ketua Umum Kelompok Keluarga Allah GSSJA), Pdt. Emmi Padang (Ketua Wilayah VI GSJA Jawa Tengah), Pdt. Elpis Sihombing (GSJA Rejosari), Pdt. Heny Pardede (GSJA Injil Sepenuh), dan Pdt. Sontina Tamba (GSJA Kristus Raja).

\section{Analisis}

Penelitian ini menggunakan meto-dologi kualitatif sehingga tidak memakai statistik dalam melakukan analisis data yang telah diperoleh. Data akan dianalisis dan dirangkum yang didasarkan atas 
kebenaran Firman Allah. Analisis data kualitatif merupakan usaha yang dilakukan melalui data, mengorganisasi data, mengklasifikasikan data menjadi satuan yang dapat dikelola, mensintesiskannya, mencari dan menemukan pola, menemukan apa yang diangggap penting, dan apa yang dipelajari, serta memutuskan apa yang diceritakan kepada orang lain. ${ }^{19}$

Analisis data dalam penelitian ini adalah sebagai berikut: ${ }^{20}$ pertama, mencatat dan memberi kode pada sumber literatur dan hasil dari wawancara tentang model pemuridan di GSJA. Berbagai catatan tersebut untuk selanjutnya diberi kode agar sumber datanya tetap dapat ditelusuri dengan baik dan rapi.

Kedua, mengumpulkan, mengklasifikasikan, mensintesis, membuat ikhtisar dan membuat indeks terhadap temuan data mengenai model pemuridan akselerasi Yesus Kristus dan dampak atau hasilnya menurut Injil Sinoptik, pakar pemuridan modern dan hasil wawancara para tokoh maupun gembala sidang GSJA.

Ketiga, membuat kategori data mengenai model pemuridan yang didapat memiliki makna, mencari serta mene-mukan hubungan antara pemuridan Yesus Kristus dalam Injil Sinoptik dan teori-teori pemuridan modern dengan pemuridan jemaat yang dilakukan oleh GSJA dalam kaitannya dengan multiplikasi jemaat.

Keempat, menganalisis hubungan antara model pemuridan Yesus Kristus dengan model pemuridan yang dilakukan oleh GSJA dalam kaitannya dengan multiplikasi jemaat. Hubungan tersebut akan terlihat dari perbandingan antara model pemuridan Yesus Kristus dan dampak atau hasilnya menurut Injil Sinoptik, serta dari pakar pemuridan modern dengan model pemuridan jemaat, dampak atau hasilnya menurut GSJA. Dari hasil perbandingan tersebut, dapat dilakukan tindakan, yaitu meninjau kekuatan dan kelemahan, untuk

${ }^{19}$ Lexy. J. Moleong, 248.

${ }^{20}$ Ibid. kemudian dirumuskan sebagai model pemu-ridan akselerasi dalam multiplikasi jemaat bagi denominasi GSJA di Indonesia pada umumnya dan GSJA di Surakarta pada khususnya pada masa sekarang.

\section{Hasil Penelitian}

\section{Model Pemuridan GSJA}

\section{Sejarah Pemuridan GSJA}

Yesus Kristus mengawali pelayanan dengan memberitakan Injil Kerajaan Allah sebelum melakukan pemuridan (Mrk. 1:14-8:30, Mat. 4:1216:20, Luk. 4:14-9:21. ${ }^{21}$ Sesudah itu Ia memanggil murid-murid (Mrk. 116-20), mengajar di Bait Suci (Mrk. 1:21-22, Luk. 4;31-32), mengusir roh jahat (Mrk. 1:23-28, Luk. 4:33-37). ${ }^{22} \quad$ Ia juga menyembuhkan hamba seorang perwira (Luk. 7:110, Mat. 8:5-13), membangkitkan anak seorang janda di Naim (Luk. 7:11-17). ${ }^{23}$ Ia mengajar dalam perumpamaan (Mrk. 4:1-34, Luk. 8:4-18, Mat. 13:152), meredakan badai (Mrk. 4:35-41, Luk. 8:22-25, Mat. 8:22-17), menaklukkan Iblis (Mrk. 5:1-20, Luk. 8:26-39, Mat. 8:28-34). ${ }^{24}$ Ia mengutus murid-murid ke desa-desa di Galilea (Mrk. 6:6b-13, Luk. 9:1-6, Mat. 10:1-11), murid-murid kembali (Mrk. 6:30, Luk. 9:10, lalu Yesus melakukan evaluasi atas pekerjaan murid-murid-Nya dan mempersilakan mereka juga untuk beristirahat (Mrk. 6:31). ${ }^{25}$

Berkenaan dengan sejarah pemuridan ini, para pakar pemuridan sepakat dan memiliki pandangan yang sama bahwa pemberitaan Injil harus

\footnotetext{
${ }^{21}$ Michael Eaton, Michael Eaton, Jesus of The Gospels, (Yogyakarta: ANDI, 2009), 107-108.

${ }^{22}$ Leith Anderson, Yesus: Biografi Lengkap tentang Pribadi-Nya, Negara-Nya, dan Bangsa-Nya, (Yogyakarta: Gloria Graffa, 2008), 111-112.

${ }^{23}$ Ibid, 115-117.

${ }^{24}$ Ibid, 118-119.

${ }^{25} \mathrm{Ibid}, 125$.
} 
menjadi titik awal dalam pemuridan. Yesus telah datang ke dunia berkorban bagi manusia dan Ia memerintahkan kepada gereja-Nya untuk membawa pria dan wanita kepada pengenalan akan Tuhan Yesus Kristus (pekabaran Injil) dan selanjutnya Allah telah memanggil gereja-Nya untuk melakukan pemuridan. ${ }^{26}$ Orang percaya harus membaktikan diri untuk meneguhkan pengalaman pertobatan seseorang yang telah diinjili dengan cara memberikan bimbingan rohani. ${ }^{27}$ Sebagai langkah awal adalah membawa orang kepada Kristus, tentunya dengan penginjilan terlebih dahulu. ${ }^{28}$

Sementara itu sejarah pemuridan GSJA dimulai dari gereja yang menyadari akan tugas untuk menyampaikan Kabar Baik (pekabaran Injil) yaitu kabar keselamatan dan kehidupan kekal bagi setiap manusia (Yoh. 3:16). ${ }^{29}$ Gereja bertanggung jawab untuk mencari jiwa, memelihara, merawat, mendewasakan, menjadikan murid Kristus yang sejati dalam suatu wadah pemuridan. tugas penggembalaan adalah menjadikan orang percaya menjadi murid Kristus.

Sesudah memberitakan Injil, Yesus Kristus mulai melayani dan mempersiapkan diri untuk pemuridan dengan prinsip-prinsip kerajaan maupun aktifitas-aktitas ilahi yang mengarah kepada pemuridan. ${ }^{30}$ Ia mulai membentuk sebuah tim pemuridan dengan tujuan agar mereka bertumbuh dan melanjutkan pekerjaan-Nya kelak.

Para pakar pemuridan modern menyarankan agar setiap orang yang diinjili mengikuti proses

\footnotetext{
${ }^{26}$ Sutherland \& Hartman, Pedoman Pemuridan, (Bandung: Kalam Hidup, 1976), 13.

${ }^{27}$ Waylon B. Moore, Penggandaan Muridmurid, (Malang: Gandum Mas, 1981), 7-8.

${ }^{28}$ T. Haryono, "Tinjauan Filosofis-Teologis KTBK," Jurnal Aletheia Transformasi Berbasis KTBK, (Surakarta, STTG, 2004), 1.

${ }^{29}$ www.gsja.org

${ }^{30}$ William MacDonald, Ikutlah Yesus, (Jakarta: Sastra Hidup Indonesia, 2004), 11.
}

pemuridan dalam wadah tertentu (gereja, kelompok pemuridan). Mereka yang telah bertobat sebagai anggota baru harus bergabung dengan gereja setempat, mengusahakan tindak lanjut dalam persekutuan yang hidup dengan jemaat setempat, serta mendidik pemimpin-pemimpin untuk dapat melayani dalam pemuridan. ${ }^{31}$ Setelah membawa manusia tersebut, baru menolong untuk bertumbuh ke arah Kristus, melatih menjadi pelayan Kristus, mengutus bagi Kristus dan mendoakan senantiasa dalam Kristus. ${ }^{32}$

Allah bermaksud membangun orang-orang percaya melalui pemuridan Kelompok Keluarga Allah, dengan target agar jemaat akan memiliki kedewasaan rohani dan karakter seperti Kristus.

Kelompok Keluarga Allah (KKA) adalah kepanjangan dari gereja-Nya untuk memuridkan jemaat Gereja Sidang Jemaat Allah (GSJA) ${ }^{33}$

Akan tetapi GSJA masih kurang dalam mengelola, melatih jemaat untuk melakukan penginjilan terhadap orang lain. Departemen Misi Nasional GSJA jarang mengadakan pelatihan bagi pelayan dan jemaat untuk mengabarkan Injil secara kontekstual, sehingga gereja lokal pun sangat kurang melatih dan memperlengkapi jemaat. Padahal jika penginjilan lemah, maka pemuridan pun menjadi lemah karena kurangnya jiwa-jiwa yang diinjili dan dimuridkan.

GSJA sangat perlu untuk memperbaiki penginjilan di dalam gereja lokal. Perbaikan bisa dengan cara mengadakan pengajaran dan pelatihan misi maupun pemuridan bagi pelayan Tuhan yang pada akhirnya akan diterapkan juga kepada jemaat gereja lokal secara intensif. Selain itu, perlu dipikirkan GSJA agar segera membentuk Departemen Pemuridan secara tersendiri, karena selama ini pemuridan masuk dalam Departemen Penginjilan. Hal ini bertujuan agar pemuridan bisa berjalan dengan baik, bahkan meningkat. Sehingga diharapkan Departemen Misi akan terus bekerjasama

\footnotetext{
${ }^{31}$ Waylon B. Moore, 7-8.

${ }^{32}$ T. Haryono, 5.

${ }^{33}$ www.gsja.org
} 
(saling berkaitan) dengan Departemen Pemuridan dalam hal penginjilan yang akan ditindaklanjuti dengan pemuridan. Fokus dari dua departemen ini adalah merekrut, melatih tenaga-tenaga penginjilan dan pemuridan. GSJA perlu menerbitkan literatur mengenai penginjilan dan pemuridan kontekstual sebagai panduan secara praktis bagi pelaksanaan pemuridan di gereja lokal.

Berdasarkan analisis di atas, maka penulis menyimpulkan bahwa GSJA telah menjadikan pemberitaan Injil sebagai awal dari pemuridan yang terlihat dari sejarah GSJA dan sejarah pemuridan GSJA. Namun, masih kurang dalam mengelola, memperlengkapi dan melatih jemaat dalam hal pemuridan. GSJA sangat perlu mengadakan pelatihan penginjilan dan pemuridan kepada pelayan Tuhan dan jemaat lokal agar jemaat bertumbuh menjadi murid sejati yang dewasa dan serupa dengan Kristus, berbuah, berlipatganda bahkan menjadi pemurid. Oleh karena itu GSJA perlu membentuk sebuah Departemen Pemuridan untuk memfasilitasi pelatihan pemuridan melalui kerja sama dengan Departemen Misi agar di dalam memuridkan jemaat semakin efektif dan efisien.

\section{Prinsip Pemuridan GSJA}

Prinsip-prinsip pemuridan Tuhan Yesus sangat runtut. Ada tiga prinsip pemuridan Yesus Kristus menurut Injil Sinoptik yaitu: seleksi (screening), pusat pelatihan (training center), serta multiplikasi (multiplication).

Para pakar pemuridan modern memiliki kesepakatan dalam prinsip-prinsip pemuridan yaitu pemilihan, pengembangan dan pelipatgandaan. Hartman \& Sutherland menjelaskan, dalam pemilihan dapat dikembangkan dengan cara yaitu: pemilihan dari antara jumlah pengikut, lingkungan sebagai tempat kelompok berfungsi, murid-murid yang potensial. ${ }^{34}$ Waylon B. Moore menulis dalam pemilihan dengan empat pendekatan pokok:

\footnotetext{
${ }^{34}$ Sutherland \& Hartman, 38, 40.
}

berkotbah, mengajar, menyembuhkan, mengadakan mujizat. ${ }^{35}$

T. Haryono menjelaskan dalam prinsip pemilihan ini dikenal dengan prinsip membentuk KTBK yang di dalamnya harus melalui beberapa langkah yaitu: berdoa, menceritakan visi-misi KTBK kepada rekan-rekan seiman, memotivasi rekan-rekan seiman agar memiliki kerinduan dan komitmen membentuk KTBK, memulai jika sudah ada minimal dua orang. ${ }^{36}$

Prinsip kedua yang menjadi persamaan dari para pakar pemuridan modern adalah prinsip pengembangan yaitu dengan cara membentuk suatu kelompok yang dinamakan kelompok pembuat murid. $^{37}$ Gereja adalah tempat memulai pemuridan dan pembinaan dan pengembangan. ${ }^{38}$ T. Haryono menulis bahwa dalam mengembangkan pemuridan KTBK dengan: memakai sistem sel, berdoa, pemimpin memberikan pelatihan kepada anggota tentang KTBK, anggota KTBK yang siap melayani mulai dicoba

memimpin KTBK. Prinsipnya adalah dipimpin, dimuridkan dan dilayani (dalam KTBK lama), sekarang memimpin, memuridkan dan melayani (dalam KTBK yang baru). ${ }^{39}$

Prinsip ketiga adalah prinsip pelipatgandaan atau multiplikasi. Hartman \& Sutherland menjelaskan pemuridan memiliki tujuan memuridkan orang-orang yang pada gilirannya akan memuridkan orang lain pula. Murid-murid yang diajar akan dapat berlipatganda (multiplikasi). ${ }^{40}$

Waylon B. Moore ${ }^{41}$ menulis bahwa multiplikasi ini harus merupakan hasil dari

\footnotetext{
${ }^{35}$ Waylon B. Moore, 29-30.

${ }^{36}$ T. Haryono, 11-14.

${ }^{37}$ Hartman \& Sutherland, 63-65.

${ }^{38}$ Waylon B. Moore, 37-40.

${ }^{39} \mathrm{~T}$. Haryono, 11-14.

${ }^{40}$ Harman \& Sutherland, 137-138.

${ }^{41}$ Waylon B. Moore, 13.
} 
pengaplikasian firman Tuhan yang diterapkan dengan sadar dan dapat dimulai dikerjakan melalui gereja lokal.

Pelipatgandaan dapat terjadi jika anggota berkomitmen dan rindu untuk bertumbuh kearah kedewasaan penuh di dalam Kristus melalui: mempelajari \& menaati Firman Allah, memiliki relasi antar anggota, ${ }^{42}$ bertumbuh secara dewasa, belajar dan taat pada Alkitab serta misioner yaitu membagikan berkat rohani bagi orang lain dengan membentuk KTBK baru. ${ }^{43}$

Pemuridan $\mathrm{KKA}^{44}$ memiliki beberapa prinsip yaitu; pertama, memahami, mengerti dan menangkap esensi dan substansi pemuridan. Kedua, mensosialisasikan. Ketiga, melakukankan pemetaan: geografis, usia, profesi, jenis kelamin. Keempat, menyiapkan sistem yang cocok untuk pemuridan. Kelima, mempromosikan pemuridan. Keenam, melaksanaan doa, puasa, koordinasi, pembagian tugas kerja dan lain sebagainya.

Pemuridan yang dilakukan oleh Yesus telah mengalami keberhasilan dikarenakan di dalam prinsip memuridkan, Yesus adalah Pemurid Sempurna. Ia mengawali pelayanannya sebelum memanggil dan memilih murid-murid dengan berdoa semalaman (Luk. 6:12-13). Yesus juga memperhatikan kebutuhan pemuridan sesuai dengan tahapnya. Terbukti Ia memulai dengan memanggil dan memilih, menemani (bersekutu), menyediakan, melatih dan membina, mengurapi, meneladankan, mengutus, mengawasi dan diakhiri dengan melipatgandakan murid atau multiplikasi. Lalu, masing-masing tahap dalam prinsip pemuridan ini memiliki cara-cara tersendiri dalam memuridkan murid-murid-Nya, baik itu mengajar, berkotbah, praktek mengusir roh jahat, bercerita, pengutusan

\section{${ }^{42} \mathrm{~T}$. Haryono, 2.}

${ }^{43}$ T. Yuliati, "Peran Roh Kudus dalam KTBK," Jurnal Aletheia Transformasi Berbasis KTBK, (Surakarta: STTG, 2004), 15.

${ }^{44}$ GSSJA, Pedoman Kelompok Keluarga Allah, (Jakarta: GSSJA, 2008), 21-23. dan lain sebagainya tergantung perkembangan tahap demi tahap dalam pemuridan. Yesus adalah Pemurid yang kreatif. Para pakar pemuridan memiliki tiga prinsip yaitu pemilihan, pengembangan dan pelipatdaaan. Mereka memiliki kekuatan dalam hal teknis. Misalnya, dalam pemilihan harus dari antara pengikut, menyediakan lingkungan, metode yang bervariasi dalam memilih, seleksi murid. $T$. Haryono menekankan pentingnya doa, membagikan visi pemuridan, memotivasi orang untuk dimuridkan. Berkenaan dengan prinsip pengembangan para pakar pemuridan modern sepakat bahwa wadah pemuridan adalah kelompok kecil, misalnya KTBK. Dan kelompok kecil pemuridan ini harus didukung oleh gereja lokal. Di dalam pemuridan harus memiliki kurikulum, materi untuk melatih dan mengajar murid-murid agar bertumbuh, dewasa, berbuah dan serupa dengan Kristus. Sehingga ketika masuk dalam prinsip pelipatgandaan, murid-murid sudah dapat memimpin kelompok kecil pemuridan bahkan bermultiplikasi secara pribadi maupun kelompok.

Sedangkan di GSJA sebenarnya perlu menerapkan prinsip lebih universal, artinya tidak harus selalu menunggu inisiatif dari gembala sidang yang menangkap visi dan esensi pemuridan, sosialisasi kepada tim pelayanan, pemetaan dan sistem sampai pelaksanaan promosi kepada jemaat lokal. Hal ini akan memakan waktu yang cukup lama, padahal banyak jiwa-jiwa yang perlu segera dimuridkan. Meskipun bukan berarti penulis berusaha menyepelekan peran gembala sidang (karena terkadang dijumpai pemimpin jemaat tidak mengerti visi gerejanya, termasuk dalam hal pemuridan), namun alangkah lebih baiknya gembala sidang perlu bergerak cepat tentunya dengan pelayan (tim) dan jemaat yang terbeban dalam pemuridan dan berdoa bersama untuk melaksanakan pemuridan. Disamping itu, perlu ditentukan dengan jelas tahaptahap dalam memuridkan, materi ataupun kurikulum yang jelas, dan target pelipatgandaan yang detail dan terukur misalnya dengan membuat informasi rencana kerja dan anggaran pemuridan (program) yang sudah tentu di dalamnya terkandung tujuan dan target pemuridan. GSJA juga perlu memberdayakan 
jemaat yang mengerti dan mempraktekkan pemuridan untuk menjadi pemurid bagi jemaat yang lain. Lepas dari kelemahan yang ada, pemuridan GSJA memiliki kekuatan di mana gembala sidang dipacu untuk berfungsi sebagai pionir pemuridan. Artinya gembala sidang harus mampu melangkah mendahului yang lain untuk melaksanakan pemuridan. Jika pemimpin berfungsi, maka anggota yang dipimpin paling tidak akan mengikuti.

Berdasarkan uraian di atas maka dapat disimpulkan bahwa GSJA perlu mengawali pemuridan dengan berdoa meminta hikmat dari Allah dan menunjukkan kebergantungannya pada pimpinan Allah. GSJA perlu meneladani dan melaksanakan sembilan prinsip pemuridan Yesus Kristus. Selain itu, GSJA perlu juga menyadari sebagai gereja (wadah, tempat dan lingkungan) yang baik untuk pelaksanaan pemuridan. Sehingga gereja harus mendukung dan terlibat dalam pemuridan ini. GSJA juga perlu melibatkan pelayan dan jemaat untuk mensukseskan pemuridan, membuat program dan anggaran pemuridan yang didalamnya mencakup hal-hal yang dibutuhkan dalam pemuridan.

\section{Komponen Pemuridan}

Guru

Yesus sebagai Guru Sejati dan Sempurna. Dari aspek keahlian, Ia cakap mengajar, berkotbah, berceramah, membuat ilustrasi, perumpamaan. Dari aspek otoritas, Ia adalah pengajar yang memiliki otoritas, wibawa, kuasa dan tanda-tanda ajaib. Dari aspek pendidik, Ia mengajarkan firman Tuhan, Roh Kudus, hidup benar, pengajaran-Nya relevan, otoritatif, dan efektif, kreatif, unik dan kontekstual. ${ }^{45}$ Dari aspek pengaruh, Ia mampu menarik perhatian orang terhadap pengajaran-Nya serta membangkitkan motivasi orang yang mendengarNya (Mrk. 12:28-34), Ia kemudian mengajukan dan

\footnotetext{
${ }^{45}$ B.S. Sidjabat, Mengajar Secara Profesional, Bandung: Yayasan Kalam Hidup, 1993), 45-47.
}

menjawab pertanyaan serta mampu memberi dan membangkitkan gairah. ${ }^{46}$

Dari aspek teknis, Ia melakukan pendekatan pemuridan individual (tutorial pribadi), dan membina kelompok yang terdiri dari dua belas murid. ${ }^{47}$ Dari aspek teladan, Yesus melakukan apa yang diajarkan-Nya, realistis dan bersahabat dengan orang-orang yang diajar-Nya, dan menjadi contoh bagi murid-murid-Nya. ${ }^{48}$

Para pakar pemuridan modern sepakat bahwa Guru sejati adalah Yesus Kristus. Guru adalah orang yang mau memuridkan orang-orang sampai menjadi murid sejati dan memuridkan orang lain juga. Guru harus terlibat dalam komunitas, menginjili menekankan pengajaran Alkitab, membangun orang di dalam Firman-Nya melalui kelompok pemahaman Alkitab, dan

memperlengkapi orang-orang percaya untuk melayani, bersaksi, hidup di dalam kuasa Roh Kudus. ${ }^{49}$ Guru harus memiliki hati sebagai orang tua. $^{50}$

Roh Kudus adalah pembimbing. Roh Kudus juga berperan bagi Pemimpin KTBK. ${ }^{51}$

Guru atau pemimpin KTBK adalah orang percaya yang dikarunia sebagai rasul, nabi, penginjil, gembala, pengajar. Fungsi guru (pemimpin) KTBK yaitu: melayani, merencanakan program \& mengevaluasi pelaksanaan KTBK), mengajar, keteladalan hidup, melatih anggota untuk melayani, pemeliharaan kelompok.

Pemimpin KTBK harus memiliki kualifikasi $^{52}$ menguasai teknik memimpin

${ }^{46} \mathrm{Ibid}, 49-51$.

${ }^{47}$ Regina M. Alfonso, How Jesus Tought, (New York: Alba House, 1986).

${ }^{48}$ H.G. Hendricks, Teaching to Change Lives, (Portland, Oregon: Multnomah Press, 1987).

${ }^{49}$ Hartman \& Sutherland, 41-44.

${ }^{50}$ Waylon B. Moore, 86-89.

${ }^{51}$ T. Yuliati, 15, 18. 
pemahaman Alkitab. Seorang pemimpin juga harus mampu menghadapi masalah-masalah dalam diskusi. $^{53}$

Dalam KKA, Guru Agung dalam KKA adalah Yesus Kristus. Sedangkan guru yang dipakai Tuhan untuk memimpin pemuridan adalah Pemimpin KKA (PKKA) sebagai koordinator pelaksanaan dan pertumbuhan KKA. PKKA bisa menjadi pemimpin, sahabat atau rekan yang membantu dalam proses pertumbuhan rohani anggota KKA. PKKA dibantu tim inti atau Komunitas Inti (Komit) yang menjadi tangan kanan dan calon PKKA jika sudah dapat bermultiplikasi. PKKA wajib membuat jadwal KKA dan petugasnya, mengisi presensi KKA, memeriksa buku jurnal saat teduh (seminggu sekali), mengunjungi anggota KKA dan melaksanaan pembinaan (mentoring) di luar jadwal KKA dan lain-lain.

GSJA mengakui bahwa Yesus adalah Guru Agung. Akan tetapi GSJA juga harus mengakui bahwa Roh Kudus sebagai Pembimbing dalam pemuridan. Guru atau PKKA harus memiliki kualifikasi dalam berbagai aspek yaitu; aspek keahlian, aspek otoritas, aspek pendidik, ${ }^{54}$ aspek pengaruh, ${ }^{55}$ aspek teknis, ${ }^{56}$ dan aspek teladan. ${ }^{57}$ Apabila PKKA memiliki kualifikasi di atas maka dipastikan KKA akan bertumbuh dan berkembang secara pesat.

\section{Murid}

\section{${ }^{52}$ Ibid, 25.}

${ }^{53} \mathrm{Ibid}, 26-27$.

${ }^{54}$ B.S. Sidjabat, Mengajar Secara

Profesional, Bandung: Yayasan Kalam Hidup, 1993), 45-47.

${ }^{55}$ Ibid, 49-51.

${ }^{56}$ Regina M. Alfonso, How Jesus Tought, (New York: Alba House, 1986), 76.

${ }^{57}$ H.G. Hendricks, Teaching to Change Lives, (Portland, Oregon: Multnomah Press, 1987), 167.
Murid adalah kelompok kecil yang memiliki peranan sebagai wakil-wakil Kristus dalam hal memberitakan Injil (Mrk. 3:13-14; 6:7, 13, Mat. 10:1-4, Luk. 6:12-16), menyampaikan pengajaran yang benar kepada orang lain (Mat. 5:19, 10:2425). ${ }^{58}$ Cirinya; memprioritaskan Yesus Kristus (Luk. 9:23), melakukan firman Allah, saat teduh dan doa teratur (Mrk 1:35), melayani, bersaksi dan (Mat.5:16), terbuka dan dapat diajar.

Murid Yesus adalah orang yang mengikut Kristus yaitu orang percaya yang sejati (Mat. 28:1920; Luk. 18:22; 9:23, 14:26-27, 33), percaya dan bersedia dimuridkan oleh guru atau pemurid, bahkan menjadi pemurid. Tujuan pemuridan adalah menjadikan murid sama seperti guru-Nya (Mat. 10:25). ${ }^{59}$ Murid-murid diperintahkan untuk meneladani Yesus. Murid-murid dijadikan sebagai rasul atau apostolos (Luk. 6:13; 9:10; 11:49; 17:5; $22: 14 ; 24: 10){ }^{60}$

Pengertian murid adalah seorang Kristen yang tidak putus-putusnya terlibat dalam firman Allah, menyerahkan nyawanya untuk orang lain, setiap hari tetap bersekutu dengan Kristus sehingga menghasilkan buah. ${ }^{61}$ Murid Kristus yang telah didoakan, dipanggil, dipilih, ditetapkan, diajar, diberi kuasa, diutus oleh Tuhan Yesus (Mat. 10:116; Mrk. 6:12-13; 9:23).

KKA menekankan keharusan murid untuk mengingat perkataan, tindakan dan gaya hidup dari gurunya. ${ }^{62}$ Murid yang baik adalah murid yang bisa

\footnotetext{
${ }^{58}$ Samuel Benyamin Haks, Pemberitaan tentang Yesus Menurut Injil-injil Sinoptik, (Bandung: Jurnal Info Media, 2008), 76.

${ }^{59}$ William MacDonald, Ikutlah Yesus, (Jakarta: Sastra Hidup Indonesia, 2004), 1, 8.

${ }^{60}$ Samuel Benyamin Hakh, 92-100.

${ }^{61}$ Waylon B. Moore, 19-21.

${ }^{62}$ Keith Philips, The Making of Disciple, (New Jersey: Fleming H. Revel Company, 1981), 15.
} 
memuridkan. ${ }^{63}$ Murid di sini adalah komunitas inti dan anggota KKA. Mereka wajib mengikuti kegiatan KKA seminggu sekali, menyerahkan buku jurnal saat teduh seminggu sekali. Mereka berhak mendapat pembinaan, buku renungan saat teduh dan buku jurnal saat teduh serta mendapatkan pelayanan yang bersifat administratif dari PKKA. Mereka akan dibina untuk bertumbuh dewasa dan berbuah serta mencari jiwa-jiwa baru untuk diajak ke KKA.

GSJA memiliki pandangan yang cukup bagus dalam hal murid, yaitu Tim Inti dan anggota KKA yang harus menaladani PKKA dan harus memuridkan orang lain. Mereka harus dapat bertumbuh melalui fasilitas yang diberikan oleh gereja, terlebih

kuasa dari Kristus yang memapukan mereka dewasa di dalam Kristen. Akan tetapi perlu diberlakukan standar waktu misalnya tiga tahun, para murid harus sudah dapat menjadi pemurid, bermultiplikasi secara pribadi maupun kelompok yaitu dengan memimpin KKA baru. Jika tidak diberlakukan standar dan target, maka murid tidak akan bergairah dan fokus untuk menjadi pemimpin baru.

\section{Relasi}

Yesus sebagai Guru yang mampu membangun relasi dengan memandang manusia secara multidimensi yang terdiri; tubuh, pikiran, rohani, pikiran, emosi hati dan suara hati, serta dimensi sosial ${ }^{64}$ dengan cara menjaga hati. ${ }^{65}$

Yesus mengajarkan para murid untuk memberi kasih dan memperhatikan bagi orang lain, kepekaaan, kasih dan perhatian pada orang lain serta mencoba membantu memberi jalan keluar bagi mereka (Mrk. 1:35-45) yang mendorong dan memotivasi seseorang untuk bertumbuh. Itulah metode persahabatan. Yesus memberikan penekanan pada relasi pribadi. Ia sering sekali

\footnotetext{
${ }^{63}$ www.perisai.net

${ }^{64}$ B.S. Sidjabat, 82 .

${ }^{65}$ Ibid, 92.
}

memanfaatkan waktu yang non formal untuk mengajarkan kebenaran kepada murid-murid-Nya. ${ }^{66}$

Menurut Hartman dan Sutherland, relasi pembuat murid dan murid adalah sahabat yang harus saling mengasihi. Waylon B. Moore menekankan relasi antara guru dan murid seperti orang tua dengan anaknya. ${ }^{67}$

Dinamika KTBK adalah relasi, interaksi, komunikasi dan diskusi antar anggota. ${ }^{68}$ Relasi bersifat interpendensi (saling ketergantungan), interaksi bersifat aktif dan menyeluruh, komunikasi bersifat timbal balik, diskusi bersifat terarah dan mendalam. ${ }^{69}$

Kelompok pemuridan KKA membangun relasi yang dibangun bersifat saling bergantung atau interdependensi dimana masing-masing anggota KKA saling membutuhkan (Ams. 17:17; Yoh. 15:13-15), komunikasi bersifat timbal balik. Selain itu diskusi cukup terarah. Pengawasan dilakukan secara bersama, akan

tetapi Pemimpin KKA memiliki kewenangan lebih untuk mengatur dan membimbing anggota KKA.

Berkenaan dengan relasi pemuridan, GSJA memiliki kekuatan karena di dalamnya terdapat relasi yang bersifat interdependensi atau saling kebergantungan dan saling membutuhkan, saling mengawasi. Hanya perlu dikembangkan relasi persahabatan antar PKKA dan anggota KKA dimana saling melihat satu dengan yang lain secara multidimensi. Komunikasi bersifat dua arah (two way traffic communication) dan diskusi harus terarah.

\section{Bahan atau Materi dan Kurikulum Pemuridan}

${ }^{66}$ Hartman \& Sutherland, 91, 95-96.

${ }^{67}$ Waylon B. Moore, 89-96.

${ }^{68}$ Soleman Kawangmani, "Relasi, Interaksi, Komunikasi dan Diskusi dalam KTBK," Jurnal Aletheia Transformasi Berbasis KTBK (Surakarta: STTG, 2004), 34.

${ }^{69}$ Ibid, 35-36. 
Yesus sebagai Guru Sempurna mempersiapkan bahan atau materi pengajaran secara lengkap, mendiskusian bahan atau materi yang Dia ajarkan kepada murid-murid-Nya ${ }^{70}$ dan menuntun Alkitab sebagai sumber materi. ${ }^{71}$ Guru untuk menyerahkan terlebih dahulu kepada Allah Bapa di sorga dan pimpinan Roh Kudus. ${ }^{72}$ Bagi Kristus, Alkitab yang adalah firman Tuhan merupakan kurikulum pemuridan. ${ }^{73}$

Bahan yang dipelajari adalah materi utama, ayat mas, dan perintah yang harus ditaati, mengajarkan cara-cara mempela-jari Alkitab, mengajarkan menghafal ayat-ayat Alkitab. ${ }^{74}$

Materi atau bahan di dalam KTBK adalah Alkitab, per kitab seri bahan KTBK yang kontekstual (bukan topikal adalah materi atau bahan KTBK. Prinsip bahan KTBK ${ }^{75}$ : dirancang meliputi tiga skope yaitu peneguhan, pembinaan dasar, pembinaan lanjutan. ${ }^{76}$ Di dalam KTBK, kurikulum dirancang sesuai dengan desain Allah, sesuai kurikulum Alkitab, sesuai visi dan misi KTBK, sesuai kebutuhan rohani peserta KTBK, setiap bahan dirancang tiga sampai empat bulan, dan berurutan per kitab serta kontekstual.

Kurikulum disediakan oleh gereja. Materi yang digunakan dalam KKA sesuai dengan kurikulum dari gereja yaitu seri pengikut Kristus 14, kurikulum kotbah gembala sesuai dengan tema

${ }^{70} \mathrm{Ibid}, 205-207$.

${ }^{71}$ Ibid, 223.

${ }^{72}$ B.S. Sidjabat, 227-228.

${ }^{73}$ William MacDonald, 8.

${ }^{74}$ Waylon B. Moore, 89-96.

${ }^{75}$ Hery Harjanto, "Bahan KTB Kontekstual, " Jurnal Aletheia Transformasi Berbasis KTBK (Surakarta: STTG, 2004), 29-32.

${ }^{76}$ Ibid, 32-33. per bulannya, dan bahan pemuridan deduktif-topikal terbitan Gandum Mas, Malang. ${ }^{77}$

GSJA perlu membuat bahan atau materi dan kurikulum dan dibagikan ke gereja-gereja lokal secara serentak. Sehingga masing-masing gereja lokal memiliki acuan dan tidak membuat sendiri tanpa ada pedoman pembuatan materi dan kurikulum. Materi dan kurikulum harus dibuat secara sistematis, berurutan menurut tingkat kerohanian, dengan belajar kitab per kitab dan studi induktif-kontekstual karena akan menghasilkan murid-murid yang cinta Alkitab, kuat dalam eksegesa dan relevansi pada masa kini. ${ }^{78}$

\section{Metode}

Yesus mengajar menggunakan metode yang salah satunya bercerita. Ia mengajar dan bercerita dengan perumpamaan (Mrk. 4:34; Luk. 8:4-15; 10:25-37; 12:16-21; 15). Banyak ilustrasi yang berupa lukisan atau gambaran yang digunakan Yesus media dalam pengajaran-Nya. ${ }^{79}$

Hartman \& Sutherland mengguna-kan metode pengajaran pengajaran secara deduktiftopikal. Metode KTBK adalah pembelajaran Alkitab secara induktif-kontekstual (inquiry). Metode di KKA juga mementingkan interaksi.

GSJA perlu mencoba menggunakan metode pemuridan yang kreatif, misalnya bercerita secara induktif-kontekstual. Perlu dihindari metode pengajaran deduktif-topikal karena akan menghasilkan murid-murid yang kuat pada ide manusia, tetapi tidak kuat dalam firman Tuhan.

\section{${ }^{77}$ Deduktif-topikal adalah cara menafsir} Alkitab dimana penafsir sudah memiliki ide tertentu sebelum mempelajari Alkitab. T. Haryono, 3.

${ }^{78}$ Induktif-kontekstual adalah cara menafsir Alkitab dengan mencari pesan asli penulis dalam konteks masa itu (sejarah, tata bahasa, budaya dan lain-lain). Penafsir terlebih dahulu menggali datadata dan fakta-fakta di dalam Alkitab untuk menemukan prinsip-prinsip kebenaran firman Tuhan secara tepat dan menerapkannya dalam konteks kehidupan sehari-hari pada masa kini. Hery Harjanto, 30.

\footnotetext{
${ }^{79}$ Robert G. Delnay, 301.
} 
Jemaat GSJA perlu diajari eksegesa, bukannya eisegese. ${ }^{80}$

\section{Akselerasi Pemuridan}

Pemuridan yang dilakukan oleh Yesus kepada murid-murid-Nya adalah pemuridan yang bersifat akselerasi yaitu hanya tiga tahun (antara 27$30 \mathrm{M}$ ), cepat tetapi dapat menciptakan murid-murid yang luar biasa yaitu mampu memberitakan Injil, memuridkan, meng-gembalakan jemaat dan lainlain.

Yesus Kristus juga memperhatikan beberapa hal antara lain: lingkungan keterlibatan murid-murid secara aktif, kolaborasi antara Yesus dan muridmurid-Nya, antar sesama murid, gaya belajar yang bervariasi dan kontekstual.

Tujuan dari pemuridan akselerasi adalah memenuhi kebutuhan murid dalam aspek kognitif dan afektif, memenuhi hak asasi murid, memenuhi minat intelektual dan perspektif masa depan murid, memenuhi kebutuhan aktualisasi diri murid, mengembangkan peran murid sebagai aset masyarakat dalam peranan atau fungsinya, menyiapkan murid sebagai pemimpin di masa yang akan datang, memberi penghargaan untuk dapat menyelesaikan pendidikan secara cepat, meningkatkan efisiensi dan efektivitas proses pembelajaran para murid, mengembangkan potensi keunggulan murid, memacu kualitas murid dalam kecerdasan spiritual, inteletual dan emosional secara berimbang). Hal itu Yesus penuhi semuanya dalam pemuridan.

Pemuridan akselerasi Yesus Kristus terdapart standar kompetensi; kualifikasi perilaku kognitif atas pimpinan Roh Kudus, murid-murid

\footnotetext{
${ }^{80}$ Eksegesa adalah usaha untuk menemukan berita utama suatu teks Alkitab dengan menerapkan prinsip-prinsip penafsiran yang sehat di mana penafsir memperhatikan tentang latar belakang sejarah, budaya, analisis kata, genre suatu teks dan lain-lain. Sedangkan eisegese adalah usaha untuk memasukkan ide penafsir ke dalam suatu teks sehingga teks itu berbicara seperti yang dikehendaki oleh penafsirnya. Beni Solihin, 7 Langkah Menyusun Kotbah yang Mengubahkan Kehidupan, (Malang: SAAT, 2010), 7.
}

dikembangkan dalam kualifikasi perilaku kreatif, kualifikasi perilaku yang bertanggungjawab, kualifikasi perilaku kecerdasan emosi, kualifikasi perilaku kecerdasan spiritual.

Gereja dapat mempengaruhi jutaan orang di seluruh dunia ini bagi Yesus Kristus, sehingga pelipatgandaan yang cepat itu sangat mungkin terjadi. ${ }^{81}$ Orang percaya dapat bermultiplikasi dengan cepat (dalam pemuridan) dengan memulai proses dinamis yang dapat menjangkau generasi penerus, bahkan terus-menerus berpengaruh pada abad yang akan datang. ${ }^{82}$

KTBK melakukan akselerasi (percepatan) pemuridan dikarenakan multiplikasi yang terusmenerus secara cepat, bergantung pada otoritas Roh Kudus dan meneladani pengajaran Kristus yang bersifat akseleratif. ${ }^{83}$

GSJA tidak membuat aturan baku dalam pemuridan sehingga setiap GSJA membuat aturan sendiri-sendiri tanpa pengawasan dari GSJA pusat. Sehingga dalam hal akselerasi pemuridan, besar kemungkinan masih sulit terjadi jika kondisi seperti ini terus terjadi, tanpa ada pembenahan yang berarti. GSJA perlu membenahi diri dalam hal akselerasi pemuridan dengan cara menetukan aturan baku mengenai pemuridan yang tidak berputar-putar pada birokrasi dan administrasi atau aturan yang menghambat percepatan. Perlu ditentukan jangka waktu pemuridan yang jelas, singkat tapi berkualitas seperti Kristus dengan menentukan kurikulum akselerasi, kolaborasi peran guru dan murid, dan pemenuhan kebutuhan murid secara holistik.

\section{Hasil Pemuridan}

Hasil pemuridan akselerasi Yesus Kristus adalah melahirkan murid atau rasul yang mengabarkan Injil ke seluruh dunia, mendirikan

\footnotetext{
${ }^{81}$ Hartman \& Sutherland, 144

${ }^{82}$ Waylon B. Moore, 13

${ }^{83}$ T. Haryono, Akselerasi Pemuridan,
} wawancara oleh Irawan Budi Lukmono, Surakarta, 5 April 2012. 
jemaat-jemaat lokal, melahirkan pemimpin baru (multiplikasi) yang akan menjadi pemurid secara terus menerus.

Menurut para pakar pemuridan modern hasil dari model pemuridan adalah bertumbuhnya muridmurid di dalam Kristus, lahirnya pemimpinpemimpin baru yang akan memuridkan dan memimpin kelompok pemuridan, munculnya kelompok-kelompok pemuridan yang baru.

Salah satu karakteristik KTBK adalah misioner $^{84}$ dan memiliki pengutusan untuk membentuk KTBK. ${ }^{85}$ Prinsip multiplikasi yang akseleratif (cepat) ${ }^{86}$ dengan cara: menetapkan sasaran, membuat perencanaan tim, pengorganisasian, pelaksanaan yang baik, penginjilan, pelatihan kepemimpinan. ${ }^{87}$

GSJA memahami bahwa hasil dari pemuridan adalah murid yang bertumbuh, lahirnya pemimpin baru dan lahirnya Kelompok Keluarga Allah yang baru. KKA harus lebih cepat (akseleratif) membawa pertumbuhan murid, melahirkan pemimpin dan KKA yang baru. Berikut beberapa analisis model pemuridan akselerasi Yesus Kristus, menurut para pakar modern dan GSJA.

Usulan Model Pemuridan Akselerasi dalam $\underline{\text { Multipilkasi Jemaat Di GSJA Surakarta }}$

\section{Sejarah Pemuridan}

Pada awal pelayanan Yesus Kristus memberitakan Injil Kerajaan Allah sebelum melakukan pemuridan (Mrk. 1:14-8:30, Mat. 4:1216:20, Luk. 4:14-9:21. Begitu pula dengan sejarah pemuridan GSJA dimulai dari gereja yang menyadari akan tugas untuk menyampaikan kabar baik (pekabaran Injil) yaitu kabar keselamatan dan

${ }^{84} \mathrm{~T}$. Haryono, 4.

${ }^{85}$ Ibid, 9.

${ }^{86}$ Christian A. Schwarz, 68

${ }^{87}$ Joel C., Ledakan Kelompok Sel, (Jakarta: kehidupan kekal bagi setiap manusia (Yoh. 3:16). Gereja bertanggung jawab untuk mencari jiwa, memelihara, merawat, mendewasakan, menjadikan murid Kristus yang sejati dalam suatu wadah pemuridan. Menjadikan orang percaya menjadi murid Kristus adalah tugas penggembalaan gereja.

Kristus ingin membangun orang-orang percaya melalui pemuridan Kelompok Keluarga Allah, dengan target agar jemaat akan memiliki kedewasaan rohani dan karakter seperti Kristus.

Kelompok Keluarga Allah (KKA) adalah kepanjangan dari gereja-Nya untuk memuridkan jemaat Gereja Sidang Jemaat Allah (GSJA). Akan tetapi GSJA masih kurang dan perlu perbaikan dalam mengelola, melatih jemaat untuk melakukan penginjilan terhadap orang lain. Departemen Misi Nasional GSJA jarang mengadakan pelatihan bagi pelayan dan jemaat untuk mengabarkan Injil secara kontekstual, sehingga gereja lokal pun sangat kurang melatih dan memperlengkapi jemaat. Padahal jika penginjilan lemah, maka pemuridan pun menjadi lemah karena kurangnya jiwa-jiwa yang diinjili dan dimuridkan.

GSJA sangat perlu untuk memperbaiki dalam penginjilan di dalam gereja lokal. Perbaikan bisa dengan cara mengadakan pengajaran dan pelatihan misi maupun pemuridan bagi pelayan Tuhan yang pada akhirnya akan diterapkan juga kepada jemaat gereja lokal secaran intensif. Selain itu, perlu dipikirkan GSJA agar membentuk Departemen Pemuridan secara tersendiri, karena selama ini pemuridan masuk dalam Departemen Penginjilan. Hal ini bertujuan agar pemuridan bisa berjalan dengan baik, bahkan meningkat. Sehingga diharapkan Departemen Misi akan dapat bekerjasama (saling berkaitan) dengan Departemen Pemuridan dalam hal penginjilan yang akan ditindaklanjuti dengan pemuridan. Fokus dari dua departemen ini adalah merekrut, melatih tenagatenaga penginjilan dan pemuridan. GSJA perlu menerbitkan literatur mengenai penginjilan dan pemuridan kontekstual.

Berangkat dari uraian di atas, maka GSJA harus tetap dan secara berkelanjutan menjadikan pemberitaan Injil sebagai awal dari pemuridan

Meta, 1998), 150. 
sebagaimana terlihat dari sejarah GSJA dan sejarah pemuridan GSJA. GSJA perlu membentuk Departemen Pemuridan yang terpisah dari Departemen Penginjilan. Kemudian GSJA perlu mengadakan pelatihan penginjilan dan pemuridan kepada pelayan Tuhan dan jemaat lokal yang difasilitasi oleh Departemen Misi bekerjasama dengan Departemen Pemuridan agar di dalam memuridkan jemaat semakin efektif, efisien. Selain itu jemaat akan bertumbuh menjadi murid sejati yang dewasa dan serupa dengan Kristus, berbuah, berlipatganda bahkan menjadi pemurid.

\section{Prinsip Pemuridan}

Prinsip-prinsip pemuridan Yesus menurut Injil Sinoptik ada tiga. Pertama, seleksi atau screening (pemahaman esensi pemuridan, promosi dan sosialisasi dengan pemanggilan, pemilihan, persekutuan, penyediaan). Kedua, pusat atau pelatihan training center (pelatihan, pengembangan, pembinaan, pengurapan, peneladanan). Ketiga, multiplikasi atau multiplication (pengutusan, pengawasan, pelipatgandaan).

KKA perlu menggabungkan sembilan prinsip pemuridan Yesus dengan menambahkan apa yang menjadi prinsip pemuridan di GSJA yaitu memahami esensi pemuridan.

Pemuridan yang Yesus lakukan mengalami keberhasilan dikarenakan di dalam prinsip memuridkan Kristus adalah Pemurid Sempurna. Ia mengawali pelayanannya sebelum memanggil dan memilih murid-murid dengan berdoa semalaman (Luk. 6:12-13). Berdoa merupakan energi yang vital dalam pemuridan. Dengan berdoa menunjukkan bahwa Ia bergantung dan memiliki kedekatan, komunikasi yang erat dengan Bapa di sorga. Ia melakukan pemuridan dengan pimpinan Allah Bapa di sorga. Doa yang terbaik datang dari kebutuhan batin yang terdalam dan kesuksesan doa terdapat di dalam hati yang tulus dan ikhlas. Yesus berdoa dengan kesungguhan hati untuk melakukan pemuridan. Di samping itu, Yesus memperhatikan kebutuhan pemuridan sesuai dengan tahapnya. Terbukti Ia memulai dengan memanggil dan memilih, menemani (bersekutu), menyediakan, melatih dan membina, mengurapi, meneladankan, mengutus, mengawasi dan diakhiri dengan melipatgandakan murid atau multiplikasi. Masingmasing tahap dalam prinsip pemuridan ini memiliki cara-cara tersendiri dalam memuridkan muridmurid-Nya, entah mengajar, berkotbah, praktek mengusir roh jahat, bercerita, pengutusan dan lain sebagainya tergantung perkembangan tahap demi tahap dalam pemuridan. Yesus adalah Pemurid yang kreatif.

GSJA sebenarnya perlu menerapkan prinsip lebih universal, artinya tidak harus selalu menunggu inisiatif dari gembala sidang yang menangkap visi dan esensi pemuridan, sosialisasi kepada tim pelayanan, pemetaan dan sistem sampai pelaksanaan promosi kepada jemaat lokal. Hal ini akan memakan waktu yang cukup lama, padahal banyak jiwa-jiwa yang perlu segera dimuridkan. Meskipun bukan berarti penulis menyepelekan peran gembala sidang (karena terkadang dijumpai pemimpin jemaat tidak mengerti visi gerejanya, termasuk dalam hal pemuridan), namun alangkah lebih baiknya gembala sidang perlu bergerak cepat tentunya dengan pelayan (tim) dan jemaat yang terbeban dalam pemuridan dan berdoa bersama untuk melaksanakan pemuridan. Disamping itu, perlu ditentukan dengan jelas tahaptahap dalam memuridkan, materi atau kurikulum yang jelas, dan target pelipatgandaan yang detail dan terukur misalnya dengan membuat informasi rencana kerja dan anggaran pemuridan (program) yang sudah tentu di dalamnya terkandung tujuan dan target pemuridan. GSJA juga perlu memberdayakan jemaat yang mengerti dan mempraktekkan pemuridan untuk menjadi pemurid bagi jemaat yang lain. Lepas dari kelemahan yang ada, pemuridan GSJA memiliki kekuatan di mana gembala sidang dipacu untuk berfungsi sebagai pionir pemuridan. Artinya gembala sidang harus mampu melangkah mendahului yang lain untuk melaksanakan pemuridan. Jika pemimpin berfungsi, maka anggota yang dipimpin paling tidak akan mengikuti.

Berdasarkan uraian di atas maka dapat disimpulkan bahwa GSJA perlu mengawali pemuridan dengan berdoa meminta hikmat dari Allah dan menunjukkan kebergantungannya pada 
pimpinan Allah. GSJA perlu meneladani dan melaksanakan sembilan prinsip pemuridan Yesus Kristus. Selain itu, GSJA perlu menyadari sebagai gereja (wadah, tempat dan lingkungan) yang baik untuk pelaksanaan pemuridan. Sehingga gereja harus mendukung dan terlibat dalam pemuridan ini. GSJA juga perlu melibatkan pelayan dan jemaat untuk mensukseskan pemuridan, membuat program dan anggaran pemuridan yang didalamnya mencakup hal-hal yang dibutuhkan dalam pemuridan.

\section{Komponen Pemuridan \\ Guru}

Yesus sebagai Guru Sejati dan Sempurna, penuh Roh Kudus (Yoh. 3:21-22) baik di lihat dari aspek keahlian, aspek otoritas, aspek pendidik, aspek teknis, dan aspek teladan. Roh Kudus adalah pembimbing.

Para pakar pemuridan modern sepakat bahwa Guru sejati adalah Yesus Kristus. Guru adalah orang yang mau memuridkan orang-orang sampai menjadi murid sejati dan mampu memuridkan orang lain juga.

Menurut GSJA, Guru Agung adalah Tuhan Yesus Kristus. Sedangkan guru yang dipakai Tuhan untuk memimpin pemuridan adalah Pemimpin KKA (PKKA) sebagai koordinator pelaksanaan dan pertumbuhan KKA. PKKA bisa menjadi pemimpin, sahabat atau rekan yang membantu dalam proses pertumbuhan rohani anggota KKA. PKKA dibantu tim inti atau Komunitas Inti (Komit) yang menjadi tangan kanan dan calon PKKA jika sudah bermultiplikasi. PKKA wajib membuat jadwal KKA dan petugasnya, mengisi presensi KKA, memeriksa buku jurnal saat teduh (seminggu sekali), mengunjungi anggota KKA dan melaksanaan pembinaan (mentoring) di luar jadwal KKA dan lain-lain.

GSJA juga harus mengakui bahwa Roh Kudus sebagai Pembimbing dalam pemuridan. Guru atau PKKA harus memiliki kualifikasi dalam berbagai aspek seperti Kristus sebagai guru sempurna. aspek keahlian, aspek otoritas, aspek pendidik, aspek pengaruh, aspek teknis, dan aspek teladan. Apabila PKKA memiliki kualifikasi di atas maka dipastikan KKA akan bertumbuh dan berkembang secara pesat. Selain itu, PKKA harus berfungsi sebagai pendidik professional, model, motivator, sahabat, pembimbing, pemurid, berhati orang tua, pengajar, pelatih, pelayan, memiliki karunia karunia yang berbeda-beda. Guru dalam hal ini tubuh Kristus atau jemaat dengan berbagai karunia Roh yang berbeda.

\section{Murid}

Murid adalah kelompok kecil yang memiliki peranan sebagai wakil-wakil Kristus dalam hal memberitakan Injil (Mrk. 3:13-14; 6:7, 13, Mat. 10:1-4, Luk. 6:12-16), menyampaikan pengajaran yang benar kepada orang lain (Mat. 5:19, 10:24-25).

Pengertian murid adalah seorang Kristen yang tidak putus-putusnya terlibat dalam firman Allah, menyerahkan nyawanya untuk orang lain, setiap hari tetap bersekutu dengan Kristus sehingga menghasilkan buah. Murid Kristus yang telah didoakan, dipanggil, dipilih, ditetapkan, diajar, diberi kuasa, diutus oleh Tuhan Yesus (Mat. 10:116; Mrk. 6:12-13; 9:23).

Murid dalam KKA harus mengingat perkataan, tindakan dan gaya hidup dari gurunya. Murid yang baik adalah murid yang bisa memuridkan. Murid di sini adalah komunitas inti dan anggota KKA. Mereka wajib mengikuti kegiatan KKA, menyerahkan buku jurnal saat teduh seminggu sekali. Mereka berhak mendapat pembinaan, buku renungan saat teduh dan buku jurnal saat teduh serta mendapatkan pelayanan yang bersifat administratif dari PKKA. Mereka akan dibina untuk bertumbuh dewasa dan berbuah serta mencari jiwa-jiwa baru untuk diajak ke KKA.

Berkenaan dengan murid, GSJA memiliki pandangan yang cukup bagus yaitu Tim Inti dan anggota KKA yang harus menaladani PKKA dan harus memuridkan orang lain. Mereka harus bertumbuh melalui fasilitas yang diberikan oleh gereja, terlebih kuasa dari Kristus yang memapukan mereka dewasa di dalam Kristen. akan tetapi perlu diberlakukan standar waktu misalnya tiga tahun, para murid harus sudah dapat menjadi pemurid, 
bermultiplikasi secara pribadi maupun kelompok yaitu dengan memimpin KKA baru. Jika tidak diberlakukan standar dan target, maka murid tidak akan bergairah dan fokus untuk menjadi pemimpin baru.

\section{Relasi}

Yesus sebagai Guru yang mampu membangun relasi dengan memandang manusia secara multidimensi yang terdiri: tubuh, pikiran, rohani, pikiran, emosi hati dan suara hati, serta dimensi sosial dengan cara menjaga hati. Yesus mengajarkan para murid untuk memberi kasih dan memperhatikan bagi orang lain, kepekaaan, kasih dan perhatian pada orang lain serta mencoba membantu memberi jalan keluar bagi mereka (Mrk. 1:35-45) yang mendorong dan memotivasi seseorang untuk bertumbuh. Itulah metode persahabatan.

Para menyampaikan bahwa relasi dalam pemuridan bersifat persahabatan, dan Interdependensi. Sedangkan dalam kelompok pemuridan KKA ini relasi yang dibangun bersifat saling bergantung atau interdependensi dimana masing-masing anggota KKA saling membutuhkan (Ams. 17:17; Yoh. 15:13-15), pola komunikasi bersifat timbal balik. Selain itu diskusi cukup terarah. Pengawasan dilakukan secara bersama, akan tetapi Pemimpin KKA memiliki kewenangan lebih untuk mengatur dan membimbing anggota KKA.

GSJA memiliki kekuatan dalam hal relasi karena terdapat relasi yang bersifat interdependensi atau saling kebergan-tungan dan saling membutuhkan, saling mengawasi. Namun perlu terus dikembangkan adalah relasi persahabatan antar PKKA dan anggota KKA dimana saling melihat satu dengan yang lain secara multidimensi. Komunikasi yang harus dikembangkan bersifat dua arah (two way traffic communication) dan diskusi harus terarah.

\section{Bahan atau Materi dan Kurikulum}

Berkenaan dengan bahan atau materi dan kurikulum, Yesus sebagai Guru Sempurna mempersiapkan bahan atau materi pengajaran secara lengkap, mendiskusian bahan atau materi yang Dia ajarkan kepada murid-murid-Nya dan menuntun Alkitab sebagai sumber materi.

Seperti pemuridan KTBK, GSJA perlu membuat bahan atau materi dan kurikulum dan dibagikan ke gereja-gereja lokal secara serentak. Sehingga masing-masing gereja lokal memiliki acuan dan tidak membuat sendiri tanpa ada pedoman pembuatan materi dan kurikulum. Materi atau bahan dan kurikulum harus dibuat secara sistematis, berurutan menurut tingkat kerohanian, dengan belajar kitab per kitab dan studi induktif-kontekstual karena akan menghasilkan murid-murid yang cinta Alkitab, kuat dalam eksegesa dan relevansi pada masa kini. Sebagai contoh bahan KTBK yang dirancang meliputi tiga skope $^{88}$. Pertama, peneguhan, yaitu bahan untuk menghantar anggota yang baru bertobat dan masih ragu-ragu tentang keselamatannya agar memiliki kehidupan iman yang teguh di dalam Kristus.

Kedua, pembinaan dasar, yaitu menolong tiap anggota bertumbuh ke arah Kristus dengan memahami dasar-dasar kekristenan. Ketiga, pembinaan lanjutan, yaitu menolong anggota untuk siap mengambil bagian dalam pelayanan dan siap menjadi pemimpin rohani, agar dapat terus bertumbuh ke arah Kristus dan melayani Tuhan.

Bahan disusun dengan pola umum sebagai berikut ${ }^{89}$ : topik, judul (singkat, menarik, dan menuntun pada materi), sasaran (apa yang diharapkan dengan pemahaman Alkitab), teks Alkitab (bagian firman Tuhan yang dibahas), teks bacaan (bagian firman Tuhan yang dibaca di rumah), introduksi (berisi pengantar singkat ke dalam pemahaman Alkitab), observasi (mencari fakta dan data Alkitab sebagai dasar untuk mengerti maksud penulis), lalu interpretasi (berisi pertanyaan penolong untuk mencoba dalam menafsirkan arti yang dimaksudkan oleh penulis Alkitab), aplikasi (langkah konkrit untuk menaati setiap kebenaran firman Tuhan yang telah dibahas), diskusi (berisi

\footnotetext{
${ }^{88}$ Hery Harjanto, 29.

${ }^{89} \mathrm{Ibid}, 31-32$.
} 
pertanyaan diskusi kontekstual untuk dipercakapkan bersama), aksi (proyek ketaatan untuk dilaksanakan oleh anggota), evaluasi (mencatat segi positif dan hambatan dalam melaksanakan aksi), dan doa (menu atau pokok doa bersama). Dalam hal ini perlu ditekankan pada prinsip hermeneutika pada tiga hal yaitu observasi, interpretasi dan aplikasi.

\section{Metode}

Berkenaan dengan mengajar, Yesus menggunakan metode yaitu bercerita. Ia mengajar dan bercerita dengan metode perumpamaan (Mrk. 4:34; Luk. 8:4-15; 10:25-37; 12:16-21; 15). Banyak ilustrasi yang berupa lukisan atau gambaran yang digunakan Yesus media dalam pengajaran-Nya.

Metode KTBK adalah pembelajaran Alkitab secara induktif-kontekstual atau inquiry. Di dalam metode di KKA juga mementingkan interaksi.

GSJA perlu mencoba menggunakan metode pemuridan yang kreatif, misalnya bercerita secara induktif-kontekstual. Perlu dihindari metode pengajaran deduktif-topikal karena metode ini menghasilkan murid-murid yang kuat pada ide manusia, tetapi tidak kuat dalam firman Tuhan.

\section{Akselerasi Pemuridan}

Pemuridan yang dilakukan oleh Yesus kepada murid-murid-Nya adalah pemuridan yang bersifat akselerasi yaitu hanya tiga tahun (antara 27$30 \mathrm{M}$ ), cepat tapi dapat menciptakan murid-murid yang luar biasa dipakai dalam pelayanan dan pemuridan. Di dalam pemuridan, Yesus Kristus juga memperhatikan beberapa hal antara lain; lingkungan keterlibatan murid-murid secara aktif, kolaborasi antara Yesus dan murid-murid-Nya, antar sesama murid, gaya belajar yang bervariasi dan kontekstual.

Pemuridan akselerasi Yesus Kristus terdapart standar kompetensi; kualifikasi perilaku kognitif atas pimpinan Roh Kudus, murid-murid dikembangkan dalam kualifikasi perilaku kreatif, kualifikasi perilaku yang bertanggungjawab, kualifikasi perilaku kecerdasan emosi, kualifikasi perilaku kecerdasan spiritual.
KTBK melakukan akselerasi (percepatan) pemuridan dikarenakan multiplikasi yang terusmenerus secara cepat, bergantung pada otoritas Roh Kudus dan meneladani pengajaran Kristus yang bersifat akseleratif.

GSJA tidak membuat aturan baku dalam pemuridan sehingga setiap GSJA membuat aturan sendiri-sendiri tanpa pengawasan dari GSJA pusat. Sehingga dalam hal akselerasi pemuridan, besar kemungkinan masih sulit terjadi jika kondisi seperti ini terus terjadi, tanpa ada pembenahan yang berarti. GSJA perlu membenahi diri dalam hal akselerasi pemuridan dengan cara menetukan aturan baku mengenai pemuridan yang tidak berputar-puatar pada birokrasi dan administrasi atau aturan yang menghambat percepatan. Perlu ditentu-kan jangka waktu pemuridan yang jelas, singkat tapi berkualitas seperti Kristus dengan menentukan kurikulum akselerasi, kolaborasi peran guru dan murid, dan pemenuhan kebutuhan murid secara holistik.

\section{Hasil Pemuridan}

Hasil pemuridan akselerasi Yesus Kristus adalah melahirkan murid atau rasul yang mengabarkan Injil ke seluruh dunia, mendirikan jemaat-jemaat lokal, melahirkan pemimpin baru (multiplikasi) yang akan menjadi pemurid secara terus menerus.

Sedangkan menurut para pakar pemuridan modern hasil dari model pemuridan adalah bertumbuhnya murid-murid di dalam Kristus, lahirnya pemimpin-pemimpin baru yang akan memuridkan dan memimpin kelompok pemuridan, munculnya kelompok-kelompok pemuridan yang baru.

GSJA memahami bahwa hasil dari pemuridan adalah murid yang bertumbuh, lahirnya pemimpin baru dan lahirnya Kelompok Keluarga Allah yang baru, penuh Roh Kudus dan memiliki karunia yang berbeda. Hanya perlu dipertajam bahwa KKA harus lebih cepat (akseleratif) membawa pertumbuhan murid, melahirkan pemimpin dan KKA yang baru serta mengarahkan bahwa perkembangan yang akseleratif itu harus diperluas jangkauannya sampai ke ujung dunia. 
Artinya dimana mereka ditempatkan, harus berfikir dan bertindak secara global.

Berikut ini tabel dan gambar tentang pemuridan akselerasi dalam multiplikasi jemaat di GSJA Surakarta. Tabel dan gambar berikut ini merusakan hasil analisis atau sintesis dan merupakan usulan model pemuridan akselerasi dalam multiplikasi jemaat di GSJA Surakarta.

\section{DAFTAR KEPUSTAKAAN}

Alfonso, Regina M., How Jesus Tought, New York: Alba House, 1986.

Anderson, Leith, Yesus: Biografi Lengkap tentang Pribadi-Nya, Negara-Nya, dan Bangsa-Nya, Yogyakarta: Gloria Graffa, 2008.

Bruce, A.B., The Training of The Twelve, Grand Rapids: Kregel Publications, 1984.

Coleman, Robert E., Rencana Agung Penginjilan, Bandung: Kalam Hidup, 1993.

Comiskey, Joel, Ledakan Kelompok Sel, Jakarta: Metanoia, 1998.

Departemen Komunikasi GSSJA, Book of Hope, Malang: Gandum Mas, 2002.

GSSJA, Pedoman Kelompok Keluarga Allah, Jakarta: GSSJA, 2008.

Hakh, Samuel Benyamin, Pemberitaan tentang Yesus Menurut Injil-injil Sinoptik, Bandung: Jurnal Info Media, 2008.

Haryono, T., Introduksi Perjanjian Baru, Surakarta: STT Gamaliel, 2010. , Jurnal KTBK, Surakarta: PMKS, 2005.

Leo, Eddy, Murid Sejati Suatu Pilihan Mutlak, Jakarta: Metanoia, 2003.
MacDonald, William, Pemuridan Sejati, Surabaya: $\mathrm{KDP},([\mathrm{t} . \mathrm{th}]$.$) .$

Moleong, Lexy, Metode Penelitian Kualitatif, Bandung: Remaja Rosdakarya, 2001.

Nawawi, Prof. Hadari \& Dra. Martini Hadari, Instrumen Penelitian Bidang Sosial, Yogyakarta: Gadjah Mada University Press, 1991.

Philips, Keith, The Making of Disciple, New Jersey: Fleming H. Revel Company, 1981.

Sidjabat, B.S., Mengajar Secara Profesional, Bandung: Yayasan Kalam Hidup, 1993.

Sutherland \& Dough Hartman, Pedoman Pemuridan, Bandung: Kalam Hidup, 1976.

Subagyo, Andreas, Bambang, Pengantar Riset Kuantitatif \& Kualitatif, Bandung: Kalam Hidup, 2004

Titi, Agustinus, Kuasa Kelompok Kecil Pemuridan, Bekasi: Saint Andrew's Ministry, 2007.

Wiyono, Gani, Gereja Sidang-sidang Jemaat Allah dalam Lintasan Sejarah, Malang: Gandum Mas, 2007 
